\title{
Dampak Mediasi Loyalitas Kerja pada Lingkungan, Motivasi, Kompensasi dan Kepuasan Kerja terhadap Kinerja Karyawan
}

\section{Mediation Impact of Work Loyalty on Environment, Motivation, Compensation and Job Satisfaction on Employee Performance}

\author{
Ustadus Sholihin ${ }^{*}$, Ririn Wahyu Arida1 \\ 1)Prodi Manajemen, Fakultas Ekonomi, Universitas Islam Kadiri, Kediri, Indonesia \\ *Coresponding Email: ustadussholihin@uniska-kediri.ac.id
}

\begin{abstract}
Abstrak
Penelitian ini bertujuan untuk menganalisis dampak lingkungan kerja, motivasi karyawan, kompensasi perusahaan, dan kepuasan kerja terhadap kinerja karyawan melalui loyalitas kerja karyawan sebagai variabel mediasi pada Rumah Sakit Ibu dan Anak (RSIA) Melinda Kediri. Penelitian ini menggunakan sampel sebanyak 50 karyawan. Teknik Sampling yang digunakan Teknik sampling jenuh. Teknik pengumpulan data menggunakan data primer dan sekunder. Teknik analisa data yang digunakan yaitu Analisa jalur atau Path Analysis dan didukung dengan perhitungan Sobel Test. Hasil analisis penelitian menunjukkan bahwa berdasar model persamaan regresi 1 lingkungan, motivasi, kompensasi dan kepuasan kerja mempunyai pengaruh positif dan signifikan terhadap loyalitas kerja karyawan. Berdasar model persamaan regresi 2, lingkungan, motivasi, kompensasi dan kepuasan kerja tidak signifikan terhadap kinerja karyawan sedangkan loyalitas kerja karyawan mempunyai pengaruh positif signifikan terhadap kinerja karyawan. Berdasar model persamaan regresi 1 dan 2 bahwa loyalitas mampu menjadi mediasi pengaruh lingkungan, motivasi, kompensasi dan kepuasan kerja terhadap kinerja karyawan Rumah Sakit Ibu dan Anak (RSIA) Melinda Kediri.
\end{abstract}

Kata Kunci: Loyalitas, Intervening, Kinerja.

\begin{abstract}
This study aims to analyze the impact of the work environment, employee motivation, company compensation, and job satisfaction on employee performance through employee work loyalty as a mediating variable at the Melinda Kediri Mother and Child Hospital (RSIA). This study used a sample of 50 employees. The sampling technique used is the saturated sampling technique. Data collection techniques using primary and secondary data. The data analysis technique used is Path Analysis and is supported by Sobel test calculations. The results of the research analysis show that based on the regression equation model 1 environment, motivation, compensation and job satisfaction have a positive and significant influence on employee work loyalty. Based on the regression equation model 2, environment, motivation, compensation and job satisfaction are not significant on employee performance, while employee work loyalty has a significant positive effect on employee performance. Based on the regression equation model 1 and 2, loyalty is able to mediate the influence of the environment, motivation, compensation and job satisfaction on the performance of the employees of the Melinda Kediri Mother and Child Hospital (RSIA).
\end{abstract}

Keywords: Loyalty, Intervening, Performance.

How to Cite: Sholihin, U. \& Arida, R.W. (2021). Dampak Mediasi Loyalitas kerja pada Lingkungan, Motivasi, Kompensasi dan Kepuasan kerja Terhadap Kinerja Karyawan. JKBM (Jurnal Konsep Bisnis dan Manajemen). 8 (1): 47-57 
Sholihin, U. \& Arida, R.W. (2021). Dampak Mediasi Loyalitas kerja pada Lingkungan, Motivasi, Kompensasi dan Kepuasan ...

\section{PENDAHULUAN}

Manajemen sumber daya manusia (MSDM) menduduki peringkat utama dalam pencapaian tujuan perusahaan, baik tujuan jangka pendek ataupun tujuan jangka panjang. Manusia sebagai human resources dalam suatu perusahaan merupakan hal terpenting dalam merealisasikan rencana-rencana dan tujuan-tujuan perusahaan (Sedarmayanti, 2013). Sumber daya manusia mempunyai peran utama dalam setiap kegiatan perusahaan. Walaupun didukung dengan sarana dan prasarana serta sumber dana yang berlebihan, tetapi tanpa dukungan sumber daya manusia yang andal kegiatan perusahaan tidak akan terselesaikan dengan baik. Hal ini menunjukkan bahwa sumber daya manusia merupakan kunci pokok yang harus diperhatikan dengan segala kebutuhannya.

Beberapa penelitian tentang kinerja karyawan yang menggunakan variable intervening antara lain:

Untuk variabel kinerja dengan hasil bahwa Komitmen organisasi berpengaruh langsung terhadap kinerja karyawan dan budaya organisasi juga berpengaruh tidak langsung terhadap kinerja karyawan melalui komitmen organisasi (Budiarti \& Bukhori, 2018).

Variabel motivasi kerja dengan hasil bahwa motivasi kerja berpengaruh langsung terhadap kinerja pegawai, tetapi motivasi kerja akan lebih besar pengaruhnya terhadap kinerja pegawai jika terlebih dahulu melalui atau ditambah dengan kepuasan kerja (Pariyanti et al., 2019). Sementara variabel kepuasan kerja dan lingklungan kerja dengan hasil bahwa kepuasan kerja tidak dapat memediasi pengaruh variabel gaya kepemimpinan dan lingkungan kerja terhadap variabel kinerja karywan (T. Siagian \& Khair, 2018).

Variabel motivasi kerja dan kepuasan kerja yang diteliti oleh Siti dengan hasil penelitian menunjukkan kepuasan kerja, motivasi kerja, dan komitmen organisasi berpengaruh baik secara langsung maupun secara tidak langsung terhadap kinerja melalui Organizational Citizenship Behavior (OCB) dengan arah positif. OCB juga terbukti mampu memediasi pengaruh kepuasan kerja, motivasi kerja dan komitmen organisasi terhadap kinerja (Nurnaningsih \& Wahyono, 2017).

Variabel kompensasi, motivasi dan kepuasan dengan hasil kompensasi secara langsung tidak berpengaruh terhadap kinerja pegawai sedangkan motivasi kerja dan kepuasan kerja berpengaruh signifikan terhadap kinerja pegawai. Kompensasi dan motivasi kerja secara tidak langsung melalui kepuasan kerja berpengaruh signifikan terhadap kinerja pegawai (Zainuri \& Mundakir, 2018).

Variabel motivasi dengan hasil bahwa motivasi kerja sebagai variabel intervening mampu memediasi hubungan kompensasi terhadap kinerja karyawan (M. Siagian, 2018).

Untuk variabel kepuasan dengan hasil bahwa kepuasan dapat memediasi hubungan antara kualitas pelayanan terhadap loyalitas pelanggan dengan hasil positif (Rizal T, 2019).

Beberapa penelitian tersebut menunjukkan adanya perbedaan hasil dalam menentukan variabel yang mempengaruhi kinerja karyawan. Oleh karena itu judul penelitian ini adalah: Dampak Mediasi Loyalitas kerja pada Lingkungan, Motivasi, Kompensasi dan Kepuasan Kerja Terhadap Kinerja Karyawan. 
Berdasar latar belakang yang telah diuraikan peneliti menentukan rumusan masalahnya sebagai berikut:

1. Adakah pengaruh lingkungan kerja, motivasi kerja, kompensasi kerja, kepuasan kerja terhadap loyalitas kerja karyawan?

2. Adakah pengaruh lingkungan kerja, motivasi kerja, kompensasi kerja, kepuasan kerja dan loyalitas kerja karyawan terhadap kinerja karyawan?

3. Adakah pengaruh lingkungan kerja terhadap kinerja karyawan dengan loyalitas kerja karyawan sebagai variabel intervening?

4. Adakah pengaruh motivasi kerja terhadap kinerja karyawan dengan loyalitas kerja karyawan sebagai variabel intervening?

5. Adakah pengaruh kompensasi kerja terhadap kinerja karyawan dengan loyalitas kerja karyawan sebagai variabel intervening?

6. Adakah pengaruh kepuasan kerja terhadap kinerja karyawan dengan loyalitas kerja karyawan sebagai variabel intervening?

Berdasarkan pada rumusan masalah di atas maka peneliti dapat menentukan tujuan penelitian sebagai berikut: 1) Untuk mengetahui dan menganalisis pengaruh lingkungan kerja, motivasi kerja, kompensasi kerja, kepuasan kerja terhadap loyalitas kerja karyawan; 2) Untuk mengetahui dan menganalisis pengaruh lingkungan kerja, motivasi kerja, kompensasi kerja, kepuasan kerja dan loyalitas kerja karyawan terhadap kinerja karyawan; 3) Untuk mengetahui dan menganalisis Pengaruh Lingkungan kerja terhadap kinerja karyawan dengan loyalitas kerja karyawan sebagai variabel intervening; 4) Untuk mengetahui dan menganalisis pengaruh motivasi kerja terhadap kinerja karyawan dengan loyalitas kerja karyawan sebagai variabel intervening; 5) Untuk mengetahui dan menganalisis pengaruh kompensasi kerja terhadap kinerja karyawan dengan loyalitas kerja karyawan sebagai variabel intervening; 6) Untuk mengetahui dan menganalisis pengaruh kepuasan kerja terhadap kinerja karyawan dengan loyalitas kerja karyawan sebagai variabel intervening.

\section{METODE PENELITIAN}

Jenis penelitian yang digunakan adalah penelitian kuantitatif. Populasi dan sampel yang digunakan dalam penelitian ini adalah semua karyawan RSIA Melinda Kediri yang berjumlah 50 karyawan. Sedangkan teknik sampling dalam penelitian ini yaitu sampel jenuh di mana semua anggota populasi dijadikan sampel penelitian (Sugiyono, 2011).

Metode pengumpulan data yang digunakan adalah data primer dengan melakukan wawancara bagian SDM RSIA Melinda Kediri. Kemudian menyebar angket melalui google form kepada seluruh karyawan RSIA Melinda Kediri yang berjumlah 50 karyawan. Adapun sumber data sekunder dalam penelitian ini berupa data pegawai, kondisi fisik perusahaan, motivasi karyawan, gaji / bonus / tunjangan, kepatuhan / ketaatan, presensi kehadiran, prestasi karyawan, peraturan perusahaan. Data tersebut sebagai bukti dan informasi dalam penelitian ini. Teknik analisa data yang digunakan adalah analisa jalur / Path analysis. Dengan menggunakan dua model persamaan regresi kemudian dianalisis tingkat mediasinya dengan mencari pengaruh tidak langsung lalu diuji dengan Sobel Test. 
Sholihin, U. \& Arida, R.W. (2021). Dampak Mediasi Loyalitas kerja pada Lingkungan, Motivasi, Kompensasi dan Kepuasan ...

\section{HASIL DAN PEMBAHASAN}

Uji statistikt pada dasarnya menunjukkan seberapa jauh pengaruh variabel independen secara individual dalam menerangkan variasi variabel dependen (Ghozali, 2011).

Berdasarkan model regresi I yaitu

$$
\mathrm{Y}=\mathrm{a}+\mathrm{b}_{1} \mathrm{X}_{1}+\mathrm{b}_{2} \mathrm{X}_{2}+\mathrm{b}_{3} \mathrm{X}_{3}+\mathrm{b}_{4} \mathrm{X}_{4}
$$

Yaitu model pengaruh dari lingkungan, motivasi, kompensasi dan kepuasan kerja terhadap loyalitas kerja karyawan. Dari hasil analisis berdasarkan tabel 1 dapat diketahui bahwa hasil pengujian masing masing variabel bebas terhadap variabel mediasi (intervening) yaitu loyalitas kerja karyawan diperoleh hasil sebagai berikut:

Tabel 1 : Model Persamaan Regresi I Coefficients

\begin{tabular}{|c|c|c|c|c|c|c|}
\hline \multirow[b]{2}{*}{ Model } & & \multicolumn{2}{|c|}{$\begin{array}{c}\text { Unstandardized } \\
\text { Coefficients }\end{array}$} & \multirow{2}{*}{$\begin{array}{c}\text { Standardized } \\
\text { Coefficients }\end{array}$} & \multirow[b]{2}{*}{$\mathrm{t}$} & \multirow[b]{2}{*}{ Sig. } \\
\hline & & $\mathrm{B}$ & Std. rror & & & \\
\hline \multirow[t]{5}{*}{1} & (Constant) & -39.274 & 9.804 & & -4.006 & .000 \\
\hline & lingkungan & .317 & .086 & .332 & 3.693 & .001 \\
\hline & motivasi & .677 & .249 & .361 & 2.722 & .009 \\
\hline & kompensasi & .837 & .257 & .448 & 3.252 & .002 \\
\hline & kepuasan & 1.137 & .334 & .306 & 3.403 & .001 \\
\hline
\end{tabular}

Hipotesis 1, lingkungan kerja memiliki $t$ hitung $>\mathrm{t}$ table sebesar 3,693 > 2,01410 dengan tingkat signifikansi sebesar 0,001 $<0,05$ hal ini menunjukkan bahwa lingkungan kerja berpengaruh positif dan signifikan terhadap loyalitas kerja karyawan. Koefisien lingkungan kerja sebesar 0,317 hal ini menunjukkan bahwa setiap kenaikan satu skor lingkungan kerja maka akan diikuti kenaikan loyalitas karyawan sebesar 0,317 dengan asumsi motivasi kerja, kompensasi kerja dan kepuasan kerja bersifat tetap. Hal ini menunjukkan bahwa lingkungan kerja berpengaruh positif dan signifikan terhadap Loyalitas karyawan. Penerimaan hipotesis pertama tersebut menjelaskan bahwa semakin tinggi lingkungan kerja yang baik yang disediakan oleh RSIA Melinda Kediri maka akan berdampak pada semakin meningkatnya loyalitas kerja karyawan di RSIA Melinda Kediri dan sebaliknya semakin jelek lingkungan kerja yang diciptakan oleh RSIA Melinda Kediri akan berdampak menurunnya tingkat loyalitas kerja karyawan.
Hasil analisis deskriptif yang dilakukan untuk variabel lingkungan kerja diukur dengan menggunakan enam indikator yaitu suhu udara di tempat kerja, tata ruang di tempat kerja, sirkulasi uadara di tempat kerja, tingkat pencahayaan di tempat kerja, hubungan antar karyawan di tempat kerja dan hubungan karyawan dengan pimpinan perusahaan di tempat kerja. Berdasarkan keenam indikator tersebut indikator tingkat pencahayaan di tempat kerja menduduki nilai mean tertinggi yaitu 4,36 dan secara keseluruhan variabel lingkungan kerja mendapatkan nilai mean yang bagus yaitu 25,4 hal ini menunjukkan bahwa RSIA Melinda Kediri telah memberikan dan memenuhi apa yang diharapkan oleh karyawan dalam bekerja. Sehingga karyawan merasakan kenyamanan dalam bekerja. Sedangkan indikator terendah yaitu hubungan karyawan dengan pimpinan perusahaan di tempat kerja sebesar 3,98 hal tersebut menunjukkan kategori yang tinggi karena RSIA Melinda Kediri sudah memberikan atau menjalin hubungan yang baik antara karyawan dengan pimpinan. 
Berdasarkan analisis di atas menunjukkan bahwa karyawan RSIA Melinda Kediri telah memberikan penilaian yang baik dan positif kepada perusahaan sehingga hal tersebut akan berdampak pada loyalitas kerja karyawan di RSIA Melinda Kediri. Hal tersebut sesuai dengan hasil penelitian t hitung $(6,984)>t$ tabel $(2,068)$ dan Sig $(0,000)<$ 0,05 . Artinya variabel lingkungan kerja berpengaruh signifikan terhadap loyalitas (Purba, 2015).

Hipotesis 2, motivasi kerja memiliki t hitung $>\mathrm{t}$ tabel sebesar 2,722 > 2,01410 Dengan tingkat signifikansi sebesar 0,009 0,05 hal ini menunjukkan bahwa motivasi kerja berpengaruh positif dan signifikan terhadap loyalitas kerja karyawan. Koefisien motivasi kerja sebesar 0,677 hal ini menunjukkan bahwa setiap kenaikan satu skor motivasi kerja maka akan diikuti kenaikan loyalitas karyawan sebesar 0,677 dengan asumsi lingkungan kerja, kompensasi kerja dan kepuasan kerja bersifat tetap.

Hal tersebut menunjukkan bahwa hipotesis dua berpengaruh positif dan signifikan jadi motivasi yang diberikan oleh RSIA Melinda Kediri sudah baik karena berdampak pada meningkatnya loyalitas kerja karyawan.

Hasil analisis deskriptif menjelaskan bahwa motivasi kerja mempunyai tiga indikator yaitu arah perilaku, tingkat usaha dan tingkat kegigihan, dari indikator tersebut indikator tingkat usaha mempunyai hasil mean tertinggi yaitu 4,46 dan indikator terendah adalah tingkat kegigihan sebesar 4,1 sedangkan arah perilaku mendapatkan mean sebesar 4,42.

Secara keseluruhan motivasi yang dilakukan oleh RSIA Melinda Kediri sudah baik karena hal tersebut akan berdampak pada kenaikan loyalitas karyawan.

Berdasarkan analisis tersebut karyawan RSIA Melinda Kediri telah memberikan penilaian motivasi kerja yang baik dan positif terhadap RSIA Melinda Kediri sehingga hal tersebut akan berdampak pada kenaikan loyalitas karyawan.

Hipotesis 3, Kompensasi kerja memi-liki t hitung $>\mathrm{t}$ tabel sebesar 3,252 > 2,01410 dengan tingkat signifikansi sebesar 0,002 $<0,05$ hal ini menunjukkan bahwa kompensasi kerja berpengaruh positif dan signifikan terhadap loyalitas kerja karyawan. Koefisien kompensasi kerja sebesar 0,837 hal ini menunjukkan bahwa setiap kenaikan satu skor kompensasi kerja maka akan diikuti kenaikan loyalitas karyawan sebesar 0,837 dengan asumsi lingkungan kerja, motivasi kerja dan kepuasan kerja bersifat tetap. Hal ini menunjukkan bahwa Hipotesis ketiga berpengaruh positif dan signifikan oleh karena itu kompensasi yang telah diberikan oleh RSIA Melinda Kediri sudah baik dan layak karena berdampak pada peningkatan loyalitas kerja karyawan.

Berdasar hasil analisis deskriptif, variabel kompensasi mempunyai empat indikator yaitu upah dan gaji, insentif, tunjangan dan fasilitas. Dari keempat indikator tersebut secara keseluruhan sudah bagus berdasar penilaian karyawan, karena kompensasi yang diberikan oleh RSIA Melinda Kediri kepada karyawan sangat layak. Karena secara keseluruhan mendapatkan nilai mean sebesar 16,64. Berdasarkan penilaian karyawan dari keempat indikator tersebut indikator upah dan gaji mendapatkan nilai mean tertinggi yaitu 4,38 dan yang terendah adalah indikator fasilitas sebesar 3,92 . 
Sholihin, U. \& Arida, R.W. (2021). Dampak Mediasi Loyalitas kerja pada Lingkungan, Motivasi, Kompensasi dan Kepuasan ...

Jadi berdasar analisis yang telah dilakukan karyawan RSIA Melinda Kediri telah memberikan penilaian yang baik dan positif mengenai kompensasi sehingga hal tersebut akan berdampak pada kenaikan loyalitas kerja karyawan.

Hipotesis 4, kepuasan kerja memiliki $t$ hitung $>\mathrm{t}$ tabel sebesar 3,403 $>2,01410$ dengan tingkat signifikansi sebesar 0,001 $<0,05$ hal ini menunjukkan bahwa kepuasan kerja berpengaruh positif dan signifikan terhadap loyalitas kerja karyawan. Koefisien kepuasan kerja sebesar 1,137 hal ini menunjukkan bahwa setiap kenaikan satu skor kepuasan kerja maka akan diikuti kenaikan loyalitas karyawan sebesar 1,137 dengan asumsi lingkungan kerja, motivasi kerja dan kompensasi kerja bersifat tetap.

Dengan demikian kepuasan kerja yang diberikan oleh RSIA Melinda Kediri kepada karyawan berdampak baik karena dapat meningkatkan loyalitas kerja karyawan. Berdasarkan analisis deskripsi hasil angket yang dibagikan kepada karyawan untuk variabel kepuasan kerja menggunakan lima indikator yaitu pekerjaan itu sendiri, gaji, promosi, pengawasan, rekan kerja.

Berdasar hasil analisis secara keseluruhan mendapatkan nilai yang baik yaitu total mean 21,68. Dan hasil tertinggi dari indikator yang digunakan adalah indikator gaji nilai mean sebesar
4,54 dan hasil terendah yaitu indikator pekerjaan itu sendiri sebesar 4,14.

Jadi berdasar analisis deskriptif penilaian karyawan kepada RSIA Melinda Kediri tentang variabel kepuasan hasilnya baik terbukti bahwa kepuasan kerja yang diberikan oleh RSIA Melinda Kediri berdampak positif dan meningkatkan loyalitas kerja.

Hasil penelitian dengan hasil sebagai berikut sesuai dengan hasil analisis diperoleh bahwa nilai t hitung sebesar 5,056 dengan perolehan nilai Sig. 0,000<0,05, artinya kepuasan kerja guru berpengaruh positif dan signifikan terhadap loyalitas guru pada taraf alpha 5\% (Simanihuruk \& Amanada, 2019).

Berdasarkan hasil analisis hipotesis satu hingga hipotesis empat, semua variabel independent mulai dari lingkungan kerja, motivasi kerja, kompensasi dan kepuasan kerja semua mempunyai pengaruh positif dan signifikan terhadap loyalitas kerja karyawan RSIA Melinda Kediri.

Tabel 2 : Model Persamaan Regresi II

\begin{tabular}{|c|c|c|c|c|c|c|}
\hline \multicolumn{7}{|c|}{ Coefficients $^{a}$} \\
\hline \multirow[b]{2}{*}{ Model } & & \multicolumn{2}{|c|}{$\begin{array}{l}\text { Unstandardized } \\
\text { Coefficients }\end{array}$} & \multirow{2}{*}{$\begin{array}{c}\text { Standardized } \\
\text { Coefficients } \\
\text { Beta }\end{array}$} & \multirow[b]{2}{*}{$\mathrm{t}$} & \multirow[b]{2}{*}{ Sig. } \\
\hline & & $\mathrm{B}$ & Std. Error & & & \\
\hline \multirow[t]{6}{*}{1} & (Constant) & 25.032 & 1.764 & & 14.188 & .000 \\
\hline & lingkungan & .004 & .015 & .033 & .240 & .811 \\
\hline & motivasi & -.051 & .041 & -.232 & -1.222 & .228 \\
\hline & kompensasi & .042 & .044 & .191 & .940 & .352 \\
\hline & kepuasan & -.095 & .058 & -.220 & -1.648 & .106 \\
\hline & loyalitas & .071 & .023 & .610 & 3.088 & .003 \\
\hline
\end{tabular}

a. Dependent Variable: kinerja

Sumber : Data diolah, 2021 
Berdasarkan model persamaan regresi II lingkungan kerja, kompensasi kerja, kepuasan keryaitu

$\mathrm{Y}=\mathrm{a}+\mathrm{b} 1 \mathrm{x} 1+\mathrm{b} 2 \mathrm{x} 2+\mathrm{b} 3 \mathrm{x} 3+\mathrm{b} 4 \mathrm{x} 4+\mathrm{bzxz}$ ja dan loyalitas kerja bersifat tetap.

Hipotesis 7, kompensasi kerja memiliki t

yaitu model pengaruh dari lingkungan kerja, hitung $<\mathrm{t}$ tabel sebesar 0,940 $<2,01537$ dengan motivasi, kompensasi, kepuasan kerja dan loyalitas tingkat signifikansi sebesar 0,352 >0,05 hal ini kerja terhadap kinerja karyawan. Dari hasil anamenunjukkan bahwa kompensasi kerja berpengalisis berdasarkan Tabel 2 dapat diketahui bahwa hasil pengujian masing masing variabel bebas terhadap variabel dependen yaitu kinerja karyawan diperoleh hasil sebagai berikut:

Hipotesis 5, lingkungan kerja memiliki t hitung $<\mathrm{t}$ tabel sebesar 0,240 $<2,01537$ dengan tingkat signifikansi sebesar 0,811 >0,05 hal ini menunjukkan bahwa lingkungan kerja berpengaruh positif dan tidak signifikan terhadap kinerja karyawan. Koefisien kompensasi kerja sebesar 0,042 hal ini menunjukkan bahwa setiap kenaikan satu skor kompensasi kerja maka akan diikuti kenaikan kinerja karyawan sebesar 0,042 dengan asumsi lingkungan kerja, motivasi kerja, kepuasan kerja dan loyalitas bersifat tetap.

Hipotesis 8, kepuasan kerja memiliki $t$ ruh positif dan tidak signifikan terhadap kinerja karyawan. Koefisien lingkungan kerja sebesar 0,004 hal ini menunjukkan bahwa setiap kenaikan satu skor lingku-ngan kerja maka akan diikuti kenaikan kinerja karyawan sebesar 0,004 dengan asumsi motivasi kerja, kompensasi kerja, kepuasan kerja dan loyalitas kerja bersifat tetap. Hal ini sejalan dengan penelitian yang dilakukan oleh Ferawati (2017) yang mengambil studi kasus pada PT Cahaya Indo Persada bahwa lingkungan kerja yang nyaman dan tingkat kedisiplinan yang tinggi akan meningkatkan kinerja karyawan.

Hipotesis 6, motivasi kerja memiliki $\mathrm{t}$ hitung $<\mathrm{t}$ tabel sebesar $-1,648<2,01537$ dengan tingkat signifikansi sebesar 0,106 > 0,05 hal ini menunjukkan bahwa kepuasan kerja berpengaruh negatif dan tidak signifikan terhadap kinerja karyawan. Koefisien kepuasan kerja sebesar (0,095) hal ini menunjukkan bahwa setiap kenaikan satu skor kepuasan kerja maka akan diikuti penurunan kinerja karyawan sebesar $(-0,095)$ dengan asumsi lingkungan kerja, motivasi kerja, kompensasi dan loyalitas kerja bersifat tetap.

Hipotesis 9, Loyalitas kerja memiliki t hitung $>\mathrm{t}$ tabel sebesar 3,088 $>2,01537$ dengan tingkat signifikansi sebesar 0,003 $<0,05$. Hal ini hitung < t tabel sebesar -1,222 < 2,01537 dengan menunjukkan bahwa loyalitas kerja berpengaruh tingkat signifikansi sebesar 0,228 $>0,05$ hal ini positif dan signifikan terhadap kinerja karyawan. menunjukkan bahwa motivasi kerja berpengaruh Koefisien loyalitas kerja sebesar 0,071 hal ini negatif dan tidak signifikan terhadap kinerja kar- menunjukkan bahwa setiap kenaikan satu skor yawan. Koefisien motivasi kerja sebesar $(-0,051)$ loyalitas kerja maka akan diikuti kenaikan kinerja hal ini menunjukkan bahwa setiap kenaikan satu karyawan sebesar 0,071 dengan asumsi lingkungskor motivasi kerja maka akan di-ikuti penurunan an kerja, motivasi kerja, kepuasan kerja dan komkinerja karyawan sebesar $(-0,051)$ dengan asumsi pensasi kerja bersifat tetap. 
Sholihin, U. \& Arida, R.W. (2021). Dampak Mediasi Loyalitas kerja pada Lingkungan, Motivasi, Kompensasi dan Kepuasan ...

Berdasarkan pengujian model persamaan Kantor Direksi PT Perkebunan Nusantara IX Divisi regresi II, baik variabel lingkungan, motivasi, Tanaman Tahunan tidak signifikan terhadap kompensasi dan kepuasan tidak ada yang signi- loyalitas kerja Berdasarkan tabel 1 \& 2 di atas, fikan terhadap kinerja karyawan hanya loyalitas maka dapat digambarkan hubungan masing-makerja yang signifikan terhadap kinerja karyawan. sing variable independent, variable intervening dan Hal ini sejalan dengan penelitian Ramadhani variable dependent serta hubungan langsung dan (2017) yang mengambil studi kasus pada Kantor hubungan tidak langsungnya pada gambar di Direksi PT Perkebunan Nusantara IX Divisi bawah ini:

Tanaman Tahunan bahwa lingkungan kerja pada

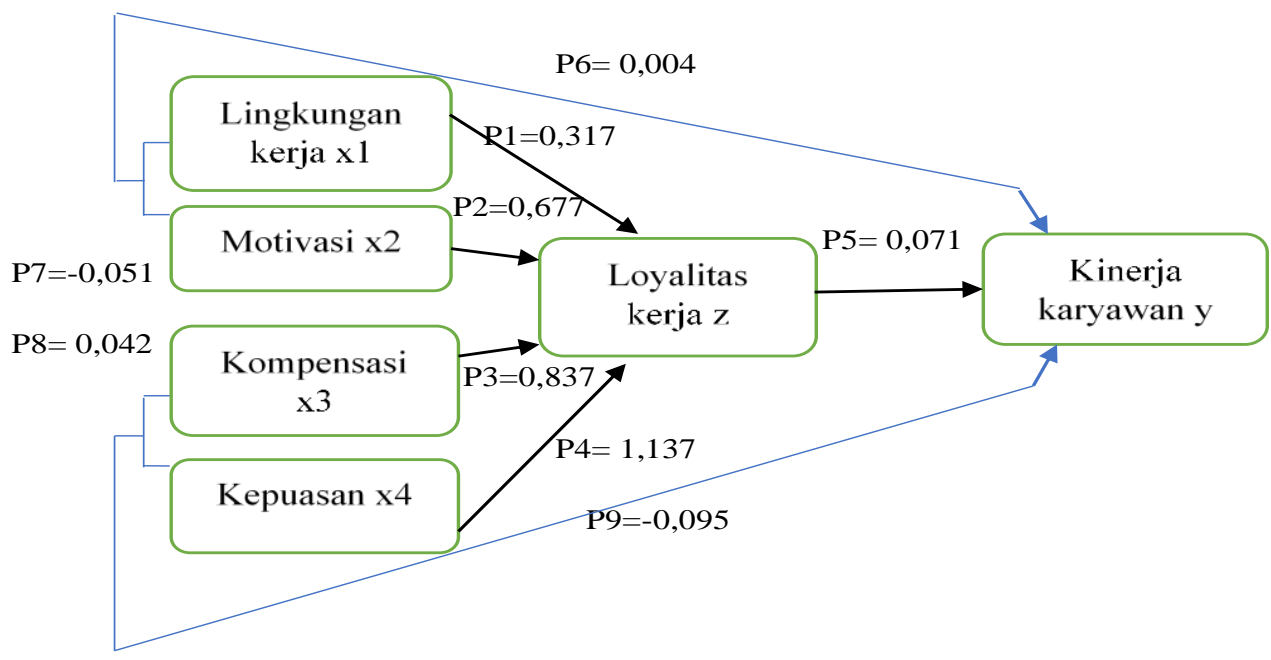

Gambar 1. Hasil Gambar Path Analysis /Analisis Jalur Sumber : Hasil Penelitian, 2021

Berdasarkan pengujian yang telah dilakukan model persamaan regresi I dan model persamaan regresi II dengan nilai koefisien yang dimasukkan ke dalam gambar dan tabel baik hubungan langsung (direct) dan hubungan tidak langsung (indirect) dari masing masing variabel untuk hubungan tidak langsung memiliki total pengaruh lebih besar dari total hubungan langsung sehingga dapat disimpulkan bahwa Loyalitas kerja karyawan mampu memediasi pengaruh lingkungan kerja, motivasi kerja, kompensasi kerja dan kepuasan kerja terhadap kinerja karyawan RSIA Melinda Kediri. Selain menggunakan tabel dan gambar di atas untuk membuktikan signifikansi atau tidaknya pengaruh mediasi $v a$ - riable intervening dapat dibuktikan dengan menggunakan perhitungan Sobel Test.

Hasil perhitungan Sobel Test dikata-kan signifikan jika nilai t statistiknya lebih besar dari 1,96. Artinya jika Sobel Test lebih besar dari t tabel variabel tersebut mampu memediasi dari variabel independent terhadap variabel dependent. Angka tersebut merupakan angka dalam tabel $t$ tak terhingga dengan menggunakan tingkat kepercayaan sebesar $5 \%$ atau 0,05 dan menggunakan uji dua arah atau dua pihak atau two tail (Sugiyono, 2011). Berdasarkan hasil perhitungan Sobel Tes untuk variabel lingkungan kerja menghasilkan nilai $\mathrm{t}$ hitung $>\mathrm{t}$ tabel yaitu 2,37 > 1,96. Sedangkan hasil perhitungan Sobel 
Test untuk variabel motivasi kerja menghasilkan nilai $\mathrm{t}$ hitung $>\mathrm{t}$ tabel yaitu $2,04>1,96$. Hasil perhitungan Sobel Test untuk variabel kompensasi kerja menghasilkan nilai $\mathrm{t}$ hitung $>\mathrm{t}$ tabel yaitu 2,24 > 1,96. Dan hasil perhitungan Sobel test untuk variabel kepuasan kerja menghasilkan nilai t hitung $>\mathrm{t}$ tabel yaitu 2,29 >1,96. Dari keempat hasil nilai Sobel Tes menunjukkan bahwa nilainya $>$ nilai t tabel atau lebih besar dari 1,96 sehingga dapat disimpulkan bahwa loyalitas kerja karyawan mampu memediasi secara signifikan dari pengaruh lingkungan kerja, motivasi kerja, kompensasi kerja dan kepuasan kerja terhadap kinerja karyawan RSIA Melinda Kediri.

Hipotesis 10, lingkungan kerja terhadap kinerja karyawan RSIA Melinda Kediri melalui loyalitas kerja karyawan Berdasarkan hasil analisis model persamaan regresi I dan II bahwa hasil pengaruh langsung dari lingkungan kerja terhadap kinerja karyawan sebesar p6 $=0,004$ sedangkan pengaruh tidak langsung dari lingkungan kerja terhadap kinerja karyawan melalui loyalitas sebesar

$$
(\mathrm{p} 1 * \mathrm{p} 5)=0,317 * 0,071=0,022507 .
$$

Sehingga diperoleh nilai total pengaruh sebesar

$6+(\mathrm{p} 1 * \mathrm{p} 5)=0,004+0,022507=0,026507$.

Sedangkan berdasarkan perhitungan Sobel Test diperoleh hasil 2,37>1,96 maka loyalitas mampu memediasi antara lingkungan kerja terhadap kinerja karyawan RSIA Melinda Kediri. Hal ini diperkuat penelitian Pane (2019) dengan mengambil lokasi di Politeknik di kota Bekasi dengan hasil bahwa budaya organisasi, Kepemimpinan, lingkungan kerja berpengaruh terhadap kinerja dosen melalui motivasi sebagai variable intervening.

Hipotesisi 11, motivasi kerja terhadap kinerja karyawan RSIA Melinda Kediri Melalui loyalitas kerja karyawan. Berdasar hasil analisis model persamaan regresi I dan II bahwa pengaruh langsung dari motivasi kerja terhadap kinerja karyawan sebesar $\mathrm{p} 7=-0,051$ sedangkan pengaruh tidak langsung dari motivasi kerja terhadap kinerja karyawan melalui loyalitas sebesar

$$
(\mathrm{p} 2 * \mathrm{p} 5)=0,677 * 0,071=0,048067 \text {. }
$$

Sehingga diperoleh nilai total pengaruh sebesar

$$
\mathrm{p} 7+(\mathrm{p} 2 * \mathrm{p} 5)=-0,051+0,048067=0,002933 .
$$

Sedangkan hasil perhitungan Sobel Test untuk variabel motivasi kerja menghasilkan nilai $t$ hitung lebih besar dari t tabel yaitu 2,04 > 1,96. Hal ini tidak sejalan dengan penelitian Sugama (2017) yang mengambil studi kasus pada Unit Layanan Pengadaan (ULP) Provinsi Bali bahwa kepuasan kerja bukan sebagai mediasi antara motivasi dan kinerja pegawai.

Hipotesis 12, kompensasi kerja terhadap kinerja karyawan RSIA Melinda Kediri melalui loyalitas kerja karyawan.

Berdasar hasil analisis hipotesa ke 12, bahwa hasil pengaruh langsung dari kompensasi kerja terhadap kinerja karyawan sebesar $p 8=0,042$ sedangkan pengaruh tidak langsungnya dari kompensasi kerja terhadap kinerja karyawan melalui loyalitas sebesar

$$
(\mathrm{p} 3 * \mathrm{p} 5)=0,837 * 0,071=0,059427 .
$$

Sehingga diperoleh nilai total pengaruh sebesar

$$
\mathrm{p} 8+(\mathrm{p} 2 * \mathrm{p} 5)=0,042+0,059427=0,101427 .
$$

Hasil perhitungan Sobel Test untuk variabel kompensasi kerja menghasilkan nilai $\mathrm{t}$ hitung 
Sholihin, U. \& Arida, R.W. (2021). Dampak Mediasi Loyalitas kerja pada Lingkungan, Motivasi, Kompensasi dan Kepuasan ...

lebih besar dari t table yaitu $2,24>1,96$. hal tersebut sejalan dengan penelitian Jufrizen (2016) yang mengambil studi kasus pada PT. Socfin Indonesia Medan kompensasi terhadap kinerja dengan kepuasan kerja sebagai variabel intervening. Hal ini diperkuat juga penelitian Sukarta \& Lestari (2019) yang mengambil lokasi pada Danoya Villa Batu Belig bahwa pengetahuan manajemen, kompensasi dan motivasi mempunyai pengaruh positif dan signifikan terhadap kinerja karyawan dengan semangat kerja sebagai variable intervening.

Hipotesis 13, kepuasan kerja terhadap kinerja karyawan RSIA Melinda Kediri melalui loyalitas kerja karyawan

Berdasar hasil analisis hipotesa ke 13 bahwa hasil pengaruh langsung dari kepuasan kerja terhadap kinerja karyawan sebesar p9= $-0,095$ sedangkan pengaruh tidak langsungnya dari kepuasan kerja terhadap kinerja karyawan melalui loyalitas sebesar

$\left(p 4^{*} p 5\right)=1,137 * 0,071=0,080727$.

Sehingga diperoleh nilai total pengaruh sebesar

$\mathrm{p} 9+(\mathrm{p} 2 * \mathrm{p} 5)=-0,095+0,08072=-0,014273$.

Dan Hasil perhitungan Sobel test untuk variabel kepuasan kerja menghasilkan nilai t hitung lebih besar dari t tabel yaitu 2,29 >1,96. Dari keempat hasil nilai Sobel menunjukkan bahwa nilainya lebih besar dari nilai $t$ tabel atau lebih besar dari 1,96 sehingga dapat disimpulkan bahwa loyalitas kerja karyawan mampu memediasi secara signifikan dari pengaruh lingkungan kerja, motivasi kerja, kompensasi kerja dan kepuasan kerja terhadap kinerja karyawan RSIA Melinda Kediri. Hasil penelitian ini sejalan de- ngan penelitian Sofyanureza (2019) yang mengambil studi kasus pada PT. INFION di Pandaan motivasi kerja terhadap kinerja karyawan melalui loyalitas sebagai variable Intervening. Hal ini diperkuat penelitian Dewi (2020) bahwa Kepuasan kerja mampu memediasi lingkungan kerja terhadap kinerja karyawan.

Berdasarkan pengujian model persamaan regresi I dan II pengujian dengan path analysis (hubungan langsung dan hubungan tidak langsung) serta perhitungan Sobel test, mulai dari hipotesis 10 hingga hipotesis ke 13 merupakan hipotesis analisis dengan variabel intervening. Menunjukkan hasil bahwa loyalitas mampu memediasi variabel independent. Hal ini sejalan dengan penelitian Nasution DA (2021) yang mengambil studi kasus pada industri perbankan telah dilakukan penelitian bahwa loyalitas mampu memediasi. Sehingga dapat disimpulkan hasil penelitian bahwa loyalitas kerja karyawan mampu memediasi pengaruh variabel variabel independen yaitu lingkungan kerja, motivasi kerja, kompensasi kerja dan kepuasan kerja terhadap kinerja karyawan RSIA Melinda Kediri. Jadi loyalitas karyawan sebagai variable intervening diterima.

\section{SIMPULAN}

Hasil analisis penelitian menunjukkan bahwa, berdasar model persamaan regresi 1 lingkungan, motivasi, kompensasi dan kepuasan kerja mempunyai pengaruh positif dan signifikan terhadap loyalitas kerja karyawan. Berdasar model persamaan regresi 2, lingkungan, motivasi, kompensasi dan kepuasan kerja tidak signifikan terhadap kinerja karyawan sedangkan loyalitas ker- 
ja karyawan mempunyai pengaruh positif dan signifikan terhadap kinerja karyawan. Berdasar model persamaan regresi 1 dan 2 bahwa loyalitas mampu memediasi lingkungan, motivasi, kompensasi dan kepuasan kerja terhadap kinerja karyawan.

\section{DAFTAR PUSTAKA}

Budiarti, T., \& Bukhori, M. (2018). Pengaruh Budaya Organisasi Terhadap Kinerja Karyawan Melalui Variabel Intervening Komitmen Organisasi Pada CV. Auto 99 Malang. Jurnal Ilmiah Bisnis Dan Ekonomi Asia, 11(2), 28-35. https://doi.org/10.32812/jibeka.v11i2.57

Dewi, N. (2020). Peran Kepuasan kerja Sebagai Variabel Intervening Memengaruhi Kinerja Karyawan. Jurnal Ilmu Manajemen (JIM), 8(2).

Ferawati, A. (2017). Pengaruh Lingkungan Kerja Dan Disiplin Kerja Terhadap Kinerja karyawan. Agora, $5(1)$.

Ghozali, I. (2011). Aplikasi Analisis Multivariat Dengan program IBM SPSS 19 (5th ed.). Badan Penerbit Universitas Diponegoro.

Jufrizen. (2016). Efek Mediasi Kepuasan Kerja Pada PengaruhKompensasi Terhadap Kinerja karyawan. Manajemen Dan Bisnis, 17(1).

Nasution DA. (2021). Pengaruh Partisipasi Anggaran Terhadap Kinerja Manajerial Dengan Tujuan Organisasi Dan Loyalitas Karyawan sebagai variabel intervening. Skripsi Universitas Islam Indonesia.

Nurnaningsih, S., \& Wahyono. (2017). Pengaruh Kepuasan Kerja, Motivasi Kerja Dan Komitmen Organisasi Terhadap Kinerja Melalui Organizational Citizenship Behavior (OCB) Sebagai Variabel Intervening. Economic Education Analysis Journal, 6(2), 365-378.

Pane, D. (2019). Pengaruh Budaya Organisasi, Kepemimpinan, Lingkungan Kerja Dan Motivasi Sebagai Variabel Intervening Terhadap Kinerja Dosen Politeknik Di Kota Bekasi. Jurnal Ilmiah Indonesia, 4(9).

Pariyanti, E., Rinnanik, R., \& Mardiono, T. (2019). Pengaruh Motivasi Kerja Terhadap Kinerja Karyawan Dengan Kepuasan Kerja Sebagai Variabel Intervening Pada PT. Federal International Finance (FIF). Relasi: Jurnal Ekonomi, 15(2), 293-307. https://doi.org/10.31967/relasi.v15i2.313
Purba, B. K. (2015). Pengaruh Kompensasi dan Lingkungan Kerja Terhadap Loyalitas Karyawan (Studi Kasus PT. Capella Dinamik Nusantara Cab. Kandis) Oleh: Journal of Chemical Information and Modeling, 53(9), 1689-1699.

Ramadhani, Z. (2017). Analisis Pengaruh Kompensasi Dan Lingkungan Kerja Fisik Terhadap Loyalitas Kerja Karyawan Melalui Kepuasan Kerja Karyawan Sebagai Variabel Intervening (Studi Pada Kantor Direksi PT Perkebunan Nusantara IX Divisi Tanaman Tahunan). UNDIP Website.

Rizal T. (2019). Pengaruh Kualitas Pelayanan Terhadap Loyalitas Nasabah Dengan Kepuasan Sebagai Variabel Intervening Pada BMT Kampoeng Syariah. Jurnal Manajemen Dan Bisnis, 1(1).

Sedarmayanti. (2013). Sumber Daya manusia Dan Produktifitas Kerja. Mandar Maju.

Siagian, M. (2018). Peranan Disiplin Kerja Dan kompensasi Dalam mendeterminasi Kinerja karyawan Dengan motivasi kerja Sebagai Variabel Intervening. JIMUPB (Jurnal Ilmiah Mananejemn Universitas Putera Batam, 6(2).

Siagian, T., \& Khair, H. (2018). Pengaruh Gaya Kepemimpinan dan Lingkungan Kerja Terhadap Kinerja Karyawan Dengan Kepuasan Kerja Sebagai Variabel Intervening. MANEGGIO Jurnal Ilmiah Magister Manajemen, 1(1), 59-70.

Simanihuruk, D., \& Amanada, A. (2019). Pengaruh kepuasan KerjaTerhadap loyalitas Kerja Guru. Prosiding Seminar Nasional Teknologi Pendidikan Pascasarjana UNIMED.

Sofyanureza, M. (2019). Pengaruh Motivasi Kerja Terhadap Kinerja Karyawan Melalui Loyalitas Sebagai Variabel Intervening Pada PT. Infion Di Pandaan. In repository.stiemahrdhika.ac.id. STIE MAHARDHIKA SURABAYA.

Sugama, I. (2017). Pengaruh Stres Kerja Dan Motivasi Terhadap Kinerja pegawai Melalui Kepuasan Kerja Sebagai Variabel Intervening Pada Unit Layanan Pengadaan (UPL) Provinsi Bali. Jurnal Ekonomi \& Bisnis, 4(1).

Sugiyono. (2011). Statistik Untuk Penelitian. Alfabeta.

Sukarta, I., \& Lestari, N. (2019). Pengetahuan Manajemen, Kompensasi, Motivasi Kerja Dalam Meningkatkan Kinerja Karyawan Dengan Semangat Kerja Sebagai Variabel Intervening. Jurnal Manajemen Bisnis, 16(3).

Zainuri, \& Mundakir. (2018). Pengaruh Kompensasi dan Motivasi Terhadap Kinerja Pegawai Negeri Sipil dengan Kepuasan Kerja Sebagai Variabel Intervening. Business Management Analysis Journal (BMAJ), 1(1), 37-48. 